\title{
Pembelajaran Tutor Sebaya: Solusi Praktis Dalam Rangka Menyongsong Pembelajaran Sastra Yang Menyenangkan Bagi Siswa SMP
}

\author{
Abdul Mukhlis ${ }^{1)}$ \\ Program Studi Pendidikan Bahasa Indonesia Program Pascasarjana Universitas Negeri Semarang \\ abdulmukhlis75@yahoo.co.id
}

\begin{abstract}
Abstrak. Permasalahan umum yang sering ditemukan dalam pembelajaran sastra adalah ketimpangan prosentase peserta didik yang menaruh minat terhadap sastra dengan yang tidak. Contoh kasus, di salah satu sekolah menengah pertama (SMP) terdapat sebagian kecil peserta didik yang menyukai sastra, baik itu puisi, prosa, dan drama. Namun, sebagian besar peserta didik lain justru sama sekali tidak menyukai sastra. Berdasarkan kasus tersebut, makalah ini memiliki tujuan: 1) memaparkan hakikat cooperative learning, 2) memaparkan hakikat metode tutor sebaya, 3) memaparkan konsep metode pembelajaran tutor sebaya, dan 4) mendeskripsikan simulasi penerapan metode turor sebaya dalam pembelajaran sastra di SMP. Model pembelajaran cooperative merupakan model pembelajaran yang prinsip utamanya adalah bekerja sama dalam satu kelompok. Model ini cocok untuk pembelajaran sastra di sekolah, baik di kelas maupun di luar kelas. Model cooperative learning yang mendukung pembelajaran sastra yaitu metode tutor sebaya (peer tutoring). Metode tutor sebaya berfokus pada kegiatan peserta didik. Dalam hal ini, peserta didik yang memiliki kemampuan dan motivasi belajar sastra yang lebih tinggi dari teman satu kelasnya, dijadikan tutor untuk membimbing teman-temannya dalam proses belajar. Dengan metode tersebut, pembelajaran sastra yang biasanya terkesan membosankan dapat berubah suasana menjadi menyenangkan. Selain itu, metode ini dapat pula menumbuhkan motivasi belajar siswa pada mata pelajaran Bahasa Indonesia khususnya bidang sastra.
\end{abstract}

Kata kunci: cooperative learning, tutor sebaya, pembelajaran sastra

\section{PENDAHULUAN}

Sastra pada hakikatnya menyangkut pembahasan mengenai nilai-nilai yang bersifat universal. Pembicaraan mengenai sastra tidak hanya dilakukan oleh para sastrawan, kritikus, maupun penikmat sastra baik secara individual atau yang tergabung dalam kelompok-kelompok diskusi sastra. Sekolah sebagai tempat menimba ilmu dan pengetahuan juga tidak ketinggalan memasukkan unsur pengkajian sastra melalui kurikulum yang diterapkan. Berkaitan dengan hal itu, tampaknya pemerintah sadar betul akan pentingnya sastra sebagai alat untuk membangun karakter setiap peserta didik.

Meminjam istilah dari Horatius (dalam Mikics, 2007:95) bahwa fungsi sastra adalah dulce et utile. Dulce dalam bahasa Latin memiliki arti sweet, artinya menyenangkan atau kenikmatan sedangkan utile atau useful berarti isinya bersifat mendidik [5]. Bertolak dari fungsifungsi itu, pemerintah dan sekolah sejatinya sudah menunjukkan keseriusan dalam melakukan upaya pembentukan karakter positif melalui pembelajaran sastra. Namun, menurut Suryatin (1999:52-53) upaya itu agaknya menghadapi kendala serius dari segi komponen sekolah yakni guru, siswa, dan sarana prasarana [13].

Secara khusus, komponen sekolah paling utama yang menghambat proses belajar mengajar selain guru adalah peserta didik. Asumsi logis yang mendasari permasalahan tersebut ialah peserta didik tidak memiliki minat untuk bersentuhan dengan hal-hal yang berbau sastra, baik itu puisi, prosa, maupun drama. Peserta didik dalam kesempatan lain sangat antusias mempelajari ilmu pengetahuan di luar ilmu-ilmu sosial. Namun begitu, hal tersebut tidak diimbangi dengan upaya menyelami ilmu sosial khususnya ilmu sastra. Permasalahan seperti itu diperparah lagi oleh komponen pokok sekolah yang lain, yakni guru yang tidak memiliki inovasi dalam membelajarkan sastra. Masalah tersebut berimplikasi terhadap pembelajaran sastra di sekolahsekolah khususnya sekolah menengah pertama (SMP) yang terkesan membosankan bagi peserta didik.

Di sisi lain, permasalahan paling dominan yang ditemui dalam pembelajaran sastra adalah ketimpangan prosentase peserta didik yang menaruh minat terhadap sastra dengan yang tidak berminat terhadap sastra. Misalnya, di salah satu sekolah menengah pertama (SMP) terdapat sebagian kecil peserta didik yang menyukai sastra, baik itu puisi, prosa, dan drama. Namun, sebagian besar peserta didik lain justru sama sekali tidak menyukai sastra. Hal ini menjadi tugas berat bagi seorang guru sastra (guru bahasa Indonesia) dalam rangka membelajarkan sastra yang menyenangkan bagi pesesrta didik. Guru dituntut melakukan inovasi pembelajaran yang kreatif sebagai jalan untuk mengatasi permasalahan tersebut.

Model-model pembelajaran dalam sastra tentu tidak semuanya dapat diterapkan untuk mengatasi permasalahan seperti di muka. Butuh kejelian dan ketelitian dari seorang guru agar upaya yang dilakukan benar-benar tepat sasaran. Dalam hal ini, guru harus memperhatikan dengan jeli jenis permasalahan paling fundamental yang sedang dihadapi. Harapannya, formula yang telah diterapkan nantinya dapat mengatasi permasalah itu dengan tepat. 
Terkait permasalahan tersebut, penulis mencoba mengusulkan model pembelajaran cooperative learning yang didukung dengan metode tutor sebaya (peer tutoring). Model pembelajaran itu merupakan model pembelajaran yang cocok diterapkan dalam ilmu-ilmu berbasis sosial termasuk sastra [12]. Sementara itu, metode tutor sebaya menunjukkan bahwa bantuan yang diberikan teman-teman sebaya pada umumnya dapat memberikan hasil yang cukup baik[14]. Teman sebaya yang diperbantukan dalam metode tutor sebaya ini adalah peserta didik yang memiliki minat tinggi terhadap sastra. Pendek kata, peran teman sebaya dapat menumbuhkan dan membangkitkan persaingan hasil belajar secara sehat karena siswa yang dijadikan tutor eksistensinya diakui oleh teman sebaya.

Berdasarkan paparan singkat ihwal latar belakang masalah di muka, makalah singkat ini mencoba menawarkan alternatif sederhana metode pembelajaran sastra yang menyenangkan bagi peserta didik melalui metode tutor sebaya. Selain itu, metode ini tampaknya cukup efektif jika digunakan oleh guru dalam pembelajaran sastra di dalam maupun di luar kelas. Secara singkat, metode pembelajaran tutor sebaya idealnya dapat diterapkan sebagai metode alternatif pembelajaran sastra yang menyenangkan bagi peserta didik.

\section{PEMBAHASAN}

Makalah ini akan membahas ihwal hakikat model pembelajaran cooperative learning, metode pembelajaran tutor sebaya (peer tutoring), prinsip pembelajaran tutor sebaya (peer tutoring), dan implementasi pembelajaran tutor sebaya dalam pembelajaran sastra. Berikut adalah uraian pembahasan dalam makalah ini.

\section{Model Pembelajaran Cooperative Learning}

Model pembelajaran cooperative learning didasari oleh semangat kerja sama antar individu dengan individu lainnya. Oleh sebab itu, secara langsung model pembelajaran ini cocok diterapkan pada mata pelajaran yang berbasis ilmu sosial. Namun, tidak menutup kemungkinan pula model ini dapat digunakan dalam pembelajaran ilmu-ilmu alam karena kultur masyarakat di Indonesia adalah mengutamakan semangat gotong royong. Hal tersebut tampaknya memunculkan kontradiksi dengan praktik di lapangan.

Memang benar bahwa model cooperative learning didasari oleh semangat gotong royong yang merupakan salah satu identitas dari bangsa Indonesia. Akan tetapi, model pembelajaran ini belum optimal dilakukan di Indonesia. Fatirul (2008:6) memberikan penjelasan mengenai penyebab model cooperative learning belum banyak diterapkan di Indonesia, alasan paling utama adalah kekhawatian bahwa akan terjadi kekacauan di kelas dan siswa tidak belajar jika mereka ditempatkan di dalam suatu grup [3]. Selain itu, banyak orang mempunyai kesan negatif mengenai kegiatan kerja sama atau belajar dalam kelompok. Banyak siswa juga tidak senang disuruh bekerja sama dengan yang lain. Siswa yang tekun merasa harus bekerja melebihi siswa yang lain dalam grup mereka, sedangkan siswa yang kurang mampu merasa minder ditempatkan dalam grup dengan siswa yang lebih pandai.

Agar lebih memahami konsep model cooperative learning, berikut dipaparkan sumbangan pemikiran dari beberapa pakar terkait hakikat model pembelajaran ini. Cooperative learning mengacu pada metode pengajaran dimana siswa bekerja bersama dalam kelompok kecil saling membantu dalam belajar [9]. Kebanyakan melibatkan siswa dalam kelompok yang terdiri dari beberapa siswa yang memiliki kemampuan yang berbeda. Selanjutnya, Sanjaya (2007:240) menyebutkan bahwa cooperative learning adalah model pembelajaran dengan menggunakan sistem pengelompokkan atau tim kecil yaitu 4 sampai 6 orang yang mempunyai latar belakang kemampuan akademik, jenis kelamin, ras atau suku yang berbeda-beda [8].

Pembelajaran kooperatif merupakan pendekatan pembelajaran yang berfokus pada penggunaan kelompok kecil siswa untuk bekerjasama dalam memaksimalkan kondisi belajar untuk mencapai tujuan belajar [10]. Isjoni (2009:15) juga mengungkapkan hal yang senada dengan beberapa pendapat para pakar sebelumnya bahwa cooperative learning adalah pembelajaran dengan mengerjakan sesuatu secara bersama-sama dengan saling membantu satu sama lainnya sebagai satu kelompok [4]. Berbeda dengan pendapat-pendapat sebelumnya, Suprijono (2009:54) mendefinisikan pembelajaran cooperative sebagai suatu konsep yang lebih luas meliputi semua jenis kerja kelompok termasuk bentuk-bentuk yang lebih dipimpin oleh guru atau diarahkan oleh guru [12].

Beberapa pendapat di atas masing-masing menunjukkan kesamaan konsep dalam pembelajaran kooperatif. Atas dasar itu, dapat disimpulkan bahwa pembelajaran coopertive learning merupakan pembelajaran yang menitikberatkan pada kegiatan kelompok, baik kelompok besar atau kecil, masing-masing kelompok tersebut berisi individu yang bersifat heterogen. Pelaksanaannya dipandu langsung oleh guru tetapi model ini tetap bisa dilakukan jika guru berhalangan hadir dalam proses belajar mengajar.

Model cooperative learning dalam pelaksanaannya perlu memperhatikan unsur-unsur yang melatarbelakangi model itu. Roger dan David (dalam Suprijono, 2009:58) menjabarkan unsur-unsur tersebut menjadi 5 poin, antara lain: a) positive independence (saling ketergantungan positif), b) personal responsibility (tanggung jawab perseorangan), c) face to face promotive interaction (interaksi promotif), d) interpersonal skill (komunikasi antaranggota), e) group processing (pemrosesan kelompok) [12].

\section{Metode Pembelajaran Tutor Sebaya (Peer Tutoring)}

Metode pembelajaran tutor sebaya (peer tutoring) adalah salah satu jenis dari model pembelajaran cooperative. 
Agar memiliki gambaran lebih jelas mengenai hakikat pembelajaran tutor sebaya, berikut ini adalah pendapat dari para ahli terkait dengan definisi metode pembelajaran tersebut. Tutor sebaya yaitu seorang atau beberapa orang murid yang ditunjuk dan ditugaskan untuk membantu muridmurid tertentu yang mengalami kesulitan belajar [14]. Bantuan yang diberikan oleh teman sebaya pada umumnya dapat menghasilkan hasil yang lebih baik. Hubungan antar murid terasa lebih dekat dibandingkan hubungan antar murid dengan guru.

Metode tutor sebaya adalah seseorang atau beberapa orang siswa yang ditunjuk oleh guru sebagai pembantu guru dalam melakukan bimbingan terhadap kawan sekelas. Penentuan seorang siswa untuk menjadi tutor bagi kawankawannya memperhatikan beberapa kriteria yang harus dimiliki oleh seorang siswa yaitu siswa yang dipilih nilai, prestasi, dan motivasi belajarnya lebih besar daripada temannya. Hakikat pengajaran tutor sebaya sebagai kegiatan belajar siswa dengan memanfaatkan teman sekelas yang mempunyai kemampuan lebih untuk membantu temannya dalam melaksanakan suatu kegiatan atau memahami suatu konsep [15].

Pendapat lain dikemukakan oleh Ahmadi dan Widodo (2004:134) yang memaparkan bahwa pembelajaran tutor sebaya adalah siswa yang ditunjuk atau di tugaskan membantu teman yang mengalami kesulitan belajar, karena hubungan teman umumnya lebih dekat dibandingkan hubungan guru dengan siswa [1]. Hakikat tutor sebaya sebagai suatu pembelajaran yang jadi murid dan yang jadi guru adalah teman sebaya juga atau umumnya itu sebaya [6]. Pengajaran tutor sebaya yang pada dasarnya sama dengan program bimbingan yang bertujuan memberikan bantuan dari dan kepada siswa supaya dapat mencapai belajar secara optimal.

Berdasarkan paparan mengenai hakikat pembelajaran tutor sebaya oleh para ahli di atas dapat disimpulkan bahwa pembelajaran tutor sebaya merupakan pembelajaran yang fokus utamanya tertuju pada siswa. Prinsipnya, siswa belajar dari siswa lain yang memiliki status umur yang tidak jauh berbeda dari dirinya sendiri sehingga anak tidak merasa begitu terpaksa untuk menerima ide-ide dan sikap dari gurunya yang tidak lain adalah teman sebayanya itu sendiri.

Tutor yang dipercaya dalam pembelajaran ini adalah teman sebaya yang memiliki motivasi belajar yang lebih tinggi dari teman-temannya, dalam hal ini beberapa peserta didik yang menaruh minat terhadap pelajaran sastra. Tutor tersebut diharapkan memberikan motivasi dan bantuan belajar kepada teman-teman sekelasnya di sekolah. Motivasi dan bantuan belajar yang dilakukan oleh teman sebaya dapat menghilangkan kecanggungan dalam proses belajar di kelas maupun luar kelas.

Uraian singkat di atas memberikan kejelasan bahwa sejak dahulu metode pembelajaran tutor sebaya sebenarnya sudah banyak diperkenalkan oleh para ahli melalui teoriteori yang ditawarkan. Hal itu dapat diamati dari kronologi atau urutan pemaparan teori dari para ahli dalam pembahasan makalah ini. Namun begitu, dari segi hakikat dan definisi metode tutor sebaya tidak mengandung perbedaan, perubahan makna atau konsep yang signifikan dari setiap pendapat. Hanya ada beberapa konsep dari para ahli saja yang mungkin berbeda dalam hal penerapannya di setiap mata pelajaran.

\section{Prinsip Pembelajaran Tutor Sebaya}

Pembelajaran tutor sebaya dapat berjalan lancar apabila prinsip-prinsip yang mendasarinya terpenuhi secara baik. Prinsip-prinsip tersebut merupakan syarat mutlak dalam metode pembelajaran ini. Syarat utama metode pembelajaran ini adalah peserta didik yang nantinya akan dijadikan tutor. Menurut Mulyadi (2008:85) penentuan peserta didik menjadi seorang tutor bagi teman-temannya harus mempertimbangkan persyaratan berikut: a) Peserta didik tersebut tergolong prestasi atau motivasi belajarnya baik, b) Peserta didik mempunyai hubungan sosial yang baik dengan teman-temannya [7]

Berbeda dengan pendapat di atas, Djamarah dan Aswan (2006:25) mengemukakan bahwa yang terpenting untuk menjadi seorang Tutor Sebaya adalah sebagai berikut: a) dapat diterima (disetujui) oleh siswa lainnya sehingga siswa tidak mempunyai rasa takut atau enggan untuk bertanya kepada tutor, b) tidak tinggi hati, kejam atau keras hati terhadap sesama kawan, c) mempunyai daya kreatif yang cukup untuk memberikan bimbingan yang dapat menerangkan pembelajaran kepada temannya [2].

Prinsip pembelajaran tutor sebaya ada 4 kriteria untuk menjadi seorang tutor sebaya antara lain, a) tutor membantu murid atau siswa yang kesulitan berdasarkan petunjuk guru, b) murid atau siswa yang dipilih sebagai tutor hendaknya diperhatikan segi kemampuan dalam penguasaan materi dan kemampuan membantu orang lain, c) dalam pelaksanaannya, tutor-tutor ini dapat membantu teman-temannya baik secara individual maupun secara kelompok sesuai petunjuk guru, d) tutor dapat berperan sebagai pemimpin dalam kegiatankegiatan kelompok, dalam hal tertentu dia dapat berperan sebagai pengganti guru [14].

Pendapat-pendapat mengenai prinsip penerapan dan syarat pemilihan unsur pelaksana (tutor) di atas memiliki perbedaan antar masing-masing tokoh. Akan tetapi, perbedaan tersebut tidak lantas membuat konsep pembelajaran tutor sebaya menjadi sulit diterapkan. Meskipun ada perbedaan dari masing-masing prinsip yang ditawarkan oleh para pakar, beberapa poin justru memiliki persamaan yang menguatkan masing-masing prinsip tersebut. Berdasarkan paparan tersebut dapat dirumuskan prinsip-prinsip utama penerapan metode tutor sebaya yang terdiri dari tutor, teman yang dibimbing, bahan ajar, dan materi yang dikuasai oleh tutor tersebut.

4. Implementasi Metode Pembelajaran Tutor Sebaya (Peer Tutoring) dalam Rangka Menyongsong Pembelajaran Sastra yang Menyenangkan di SMP

Pembelajaran yang baik adalah pembelajaran yang menarik dan mampu mendayagunakan kemampuan siswa secara optimal. Di subbab latar belakang telah diuraikan ihwal permasalahan yang menjadi pijakan dalam penulisan makalah ini. Sebagai gambaran ulang, permasalahan yang ditemui adalah seputar ketimpangan prosentase siswa 
peminat pelajaran sastra yang sangat kecil dibanding siswa yang tidak menyukai sastra. Berdasar hal itulah, metode pembelajaran tutor sebaya ditawarkan sebagai alternatif baru untuk mengatasi permasalahan tersebut. Berikut adalah skenario sederhana yang berupa tahap-tahap implementasi metode pembelajaran tutor sebaya dalam pembelajaran sastra yang didasari oleh sebuah kasus.

Kasus: Di sebuah sekolah menengah pertama (SMP) Negeri 3 Batang (Jawa Tengah), terdapat beberapa siswa yang suka terhadap sastra (baik puisi, prosa, dan drama). Akan tetapi, sebagian besar siswa tidak menaruh minat terhadap sastra (baik puisi, prosa, dan drama). Bagaimana langkah yang diterapkan guna mengatasi hal tersebut?

a. Tahap Persiapan, meliputi:

1) Pemilihan tutor. Pemilihan tutor didasarkan oleh kriteria atau prinsip pemilihan tutor. Dalam hal ini, mula-mula yang dijadikan bahan pertimbangan adalah peserta didik yang memiliki motivasi atau minat belajar sastra lebih tinggi dibanding temantemannya.

2) Apabila pembelajaran dilakukan secara klasikal, guru memandu kelas dengan membentuk kelompok heterogen dan menunjuk seorang tutor. Jika dilakukan di luar jam belajar klasikal, guru membentuk kelompok dan menunjuk seorang tutor yang akan memandu diskusi di tempat yang telah disepakati.

3) Tutor diberikan pemahaman penguasaan materi agar mereka percaya diri menghadapi teman-temannya.

b. Tahap Pelaksanaan menurut [1] meliputi:

1) Pemantapan, yaitu memantapkan pengetahuan yang dimiliki oleh siswa sesuai dengan modul yang telah dipelajari sebelumnya.

2) Pengayaan, yaitu memperluas pengetahuan dan pengalaman siswa sehingga hal-hal yang telah dipelajari dari modul menjadi lebih jelas, luas dan terpadu.

3) Bimbingan, yaitu membantu peserta dalam mengatasi kesulitan dan pemecahan masalah.

4) Perbaikan, yakni memperbaiki kelemahan atau kekurangan-kekurangan siswa dalam mempelajari materi modul, melalui pengajaran remedial.

5) Pembinaan, yaitu membina para siswa terutama dalm hal belajar mandiri, pembuatan tugas-tugas, prosedur penilaian dan lain-lain.

Tahap-tahap pembelajaran tutor sebaya ini dapat diterapkan dalam pembelajaran yang bersifat klasikal maupun yang bersifat nonklasikal. Meski cukup efektif diterapkan dalam pembelajaran sastra, ada beberapa kelemahan dan kelebihan di dalam pelaksanaannya. Berikut adalah kelebihan dan kelemahan pembelajaran tutor sebaya menurut [1]

1) Kelebihan metode tutor sebaya adalah adanya hubungan yang lebih dekat dan akrab, dapat meningkatkan rasa tanggung jawab dan kepercayaan diri, tutor sendiri kegiatannya merupakan pengayaan dan menambah motivasi belajar.
2) Kelemahan metode tutor sebaya yaitu siswa yang dibantu sering kali kurang serius karena berhadapan dengan temannya sendiri, sehingga hasilnya kurang memuaskan.

Berdasarkan kelebihan dan kekurangan penerapan metode pembelajaran tutor sebaya di atas, harapannya guru dapat mengambil pelajaran dan mengantisipasi kelemahan dalam pelaksanaan pembelajaran sastra. Dengan demikian, guru dan siswa dapat mencapai tujuan pembelajaran yang diinginkan. Kemudian, poin paling penting ihwal penerapan metode pembelajaran tutor sebaya ini adalah peserta didik menjadi tidak bosan ketika mengikuti proses belajar baik di dalam maupun di luar kelas.

Pada dasarnya bagian ini menjelaskan bagaimana penelitian itu dilakukan. Materi pokok bagian ini adalah: (a) rancangan penelitian; (b) populasi dan sampel (sasaran penelitian); (c) teknik pengumpulan data dan pengembangan instrumen; (d) dan teknik analisis data. Untuk penelitian yang menggunakan alat dan bahan, perlu dituliskan spesifikasi alat dan bahannya. Spesifikasi alat menggambarkan kecanggihan alat yang digunakan sedangkan spesifikasi bahan menggambarkan macam bahan yang digunakan.

Untuk penelitian kualitatif seperti penelitian tindakan kelas, etnografi, fenomenologi, studi kasus, dan lain-lain, perlu ditambahkan kehadiran peneliti, subyek penelitian, informan yang ikut membantu beserta cara-cara menggali data-data penelitian, lokasi dan lama penelitian serta uraian mengenai pengecekan keabsahan hasil penelitian.

Sebaiknya dihindari pengorganisasian penulisan ke dalam "anak sub-judul" pada bagian ini. Namun, jika tidak bisa dihindari, cara penulisannya dapat dilihat pada bagian "Hasil dan Pembahasan".

\section{SIMPULAN DAN SARAN}

\section{SIMPULAN}

Uraian pembahasan dalam makalah ini dapat kerucutkan menjadi poin-poin penting sebagai simpulan. Berikut adalah simpulan makalah ini: 1) Pembelajaran coopertive learning merupakan pembelajaran yang menitikberatkan pada kegiatan kelompok, baik kelompok besar atau kecil, masing-masing kelompok tersebut berisi individu yang bersifat heterogen. Pelaksanaannya dipandu langsung oleh guru tetapi model ini tetap bisa dilakukan jika guru berhalangan hadir dalam proses belajar mengajar. 2) Pembelajaran tutor sebaya merupakan pembelajaran yang fokus utamanya tertuju pada siswa. Prinsipnya, siswa belajar dari siswa lain yang memiliki status umur yang tidak jauh berbeda dari dirinya sendiri. 3) Prinsip-prinsip utama penerapan metode tutor sebaya terdiri dari tutor, teman yang dibimbing, bahan ajar, dan materi yang dikuasai oleh tutor tersebut. 4) Tahap implementasi pembelajaran tutor sebaya dalam pembelajaran sastra dilakukan berdasarkan tahap persiapan dan tahap pelaksanaan. 
Metode pembelajaran tutor sebaya tentu bukanlah satusatunya metode yang dapat diterapkan dalam menyongsong pembelajaran sastra yang menyenangkan bagi siswa SMP. Oleh karena itu, makalah singkat ini masih perlu banyak penyempurnaan dan pengujian di lapangan secara intens. Penulis berharap ada penulis atau peneliti lain yang mengembangkan konsep dan skenario implementasi metode tutor sebaya dalam pembelajaran sastra, lebih-lebih melakukan pengujian secara intens untuk mendapatkan simpulan yang valid.

\section{DAFTAR PUSTAKA}

[1] Ahmadi, Abu dan Joko. 2004. Psikologi Belajar Edisi Revisi. Jakarta: Rineka Cipta.

[2] Djamarah, Syaiful Bahri \& Aswan Zain. 2006. Strategi Belajar Mengajar. Jakarta: Rineka Cipta.

[3] Fatirul, Ahmad Noor. 2008. Model-model Pembelajaran Cooperative Learning.

http://trimanjuniarso.files.wordpress.com/2008/02/cooperative-

learning.pdf. (Diunduh pada 15 Juni 2016).

[4] Isjoni. 2009. Cooperative Learning. Bandung: Alfabeta.

[5] Mikics, David. 2007. A New Handbook of Literary Term. London: Yale University Press.

[6] Mukti, $\quad$ Bayu. 2009. Tutor Sebaya. http://www.bayumukti.com/23062009. (Diunduh pada 15 Juni 2016).

[7] Mulyadi. 2008. Diagnosis Kesulitan Belajar dan Bimbingan terhadap Kesulitan Belajar Khusus. Malang: Nuha Litera.

[8] Sanjaya, Wina. 2007. Strategi Pembelajaran: Berorientasi Standar Proses Pendidikan. Jakarta: Kencana.

[9] Slavin, Robert E. 1995. Cooperative Learning. United states of America: Printed Models.

[10] Sugiyanto. 2008. Model-model Pembelajaran Inovatif. Surakarta: Handout Panitia Sertifikasi Guru Rayon 13.

[11] Suharsimi, Arikunto. 1986. Pengelolaan Kelas dan Siswa Sebuah Pendekatan Evaluatif. Jakarta: Rajawali.

[12] Suprijono, Agus. 2009. Cooperative Learning: Teori dan Aplikasi PAIKEM. Yogyakarta: Pustaka Pelajar.

[13] Suryatin, H.E. 1997. "Efektivitas Model Mengajar Resepsi dan Pendekatan Resepsi Sastra dalam Pengajaran Sastra untuk Meningkatkan Kemampuan Apresiasi Sastra”. Disertasi. Bandung: PPS-IKIP.

[14] Suryo dan Amin. 1984. Pengajaran Remedial untuk SPG. Jakarta: Depdikbud.

[15] Winataputra. 1999. Pendekatan Pembelajaran Kelas Rangkap. Jakarta: Depdikbud. 